\title{
ANALISIS KONFIGURASI PAJAK DAERAH DI KOTA DEPOK (TAHUN 2000 - 2004)
}

\author{
Eka Sri Sunarti ${ }^{1}$
}

\author{
Abstrak
}

This research focuses on four questions and purposes, namely; (a) the great of contribution of the local original income (PAD) to the Local Budget $(A P B D) ;(b)$ the great of contribution of the local taxes to the Local Original Income (PAD); (c) variation of collecting different kinds of local taxes on any district in Depok City, and (d) the factors having impact on such variation. The research in Depok City in the consideration of the City statute has just been given in the beginning of the effective of the Law No. 22 of 1999 concerning Local Government and the Law No. 25 of 1999 on the Finance Balance between the Central Government and Local Government. This research is a qualitative research using data in five years period, from 2000 until 2004. The data variations are limited on 2004. The secondary data has been obtained through document studies such as local budget, annual report, local regulations and local monograph. The research results show that the contribution of local original income (PAD) to the local budget is still small. In this case means that Depok City is depending on central government's grant to carry out its services and society's development. The other finding shows that the contribution of the local original income (PAD) resembles the contribution of the local original income (PAD). This case means that public service is unable to be fully carried out yet as expected by the Law No. 22 of 1999 on Local Government. Beside that it is found the variation of income on different tax among districts as the impact of the variation of the district potential and condition of human resources working at the Office of Local Income. Based on the research results, it is recommended that it is necessary to make intensification rather than extensification to the collection of local taxes and conduct a research on the performance of human resources working at the Office of Local Income in Depok City.

Kata kunci: pajak, otonomi daerah, pendapat asli daerah (PAD)

\footnotetext{
${ }^{1}$ Penulis adalah Staf Pengajar Fakultas Hukum Universitas Indonesia.
} 


\section{Pendahuluan}

\section{A. Latar Belakang}

Dalam pustaka ilmu sosial dan hukum, Negara Kesatuan Republik Indonesia sering disebut sebagai negara kesatuan yang berdesentralisasi (decentralized unitary state; gedecentraliseerde eenheidsstaat). Menurut data jumlah negara, pada 2001 terdapat 168 negara kesatuan dari 192 negara, di antaranya 20 merupakan negara kesatuan yang berdesentralisasi dengan elemen federal. ${ }^{2}$ Indonesia tergolong ke dalam 20 negara tersebut. Penilaian Shah dan Thompson tersebut didasarkan pada program desentralisasi yang dicanangkan Indonesia melalui Undang-Undang Nomor 22 Tahun 1999 Tentang Pemerintahan Daerah dan Undang-Undang Nomor 25 Tahun 1999 Tentang Perimbangan Keuangan Antara Pemerintah Pusat dan Daerah.

Kecuali perode RIS pada 1949, sejak Hindia Belanda selalu dianut negara kesatuan dan sejak Undang-Undang Desentralisasi Tahun 1903 selalu diselenggarakan desentralisasi di Indonesia. Oleh karena itu, dari jumlah daerah otonom yang telah terbentuk dalam rangka desentralisasi masa kini di antaranya adalah daerah otonom yang pernah terbentuk di jaman Hindia Belanda, dengan sebutan provincie, regenschap dan stadsgemeente.

Menurut penjelasan Pasal 18 UUD 1945 sebelum amandemen, negara kesatuan (eenheidsstaat) Indonesia tidak akan mempunyai daerah di dalam lingkungannya yang bersifat staat juga. Dengan demikian, negara kesatuan merupakan negara tunggal. Dalam negara kesatuan terdapat hanya sebuah badan pembentuk undang-undang (legislature). Pendapat tersebut dikemukakan, antara lain, oleh Strong. ${ }^{3}$ Oleh karena itu, menurut Kranenburg ${ }^{4}$ daerah otonom yang

2 Nawar Shah \& Theresa Thompson, "Implementing Decentralized Local Government: A Treacherous Road With Potholes, Detours and Road Closure: prepared for "can decentralization help Rebuild Indonesia"?", A Conference Sponsored by the International Studies Program, Andrew Young School of Policy Studies, Georgia State University, Atlanta, May 1-3, 2001, hal. 1.

${ }^{3}$ CF. Strong, "Modern Political Constitution: An Introduction to the Comparative Study of Their History and Exciting Fa", (London: Sidgwick \& Jackson Limited, 1960), hal. 80 .

${ }^{4}$ R. Kranenburg, "Algemene Staatsleer", (Haarlem: H.D. Tjeenk Willink \& Zoon N.V. 1955), hal. 154-155. 
dibentuk tidak akan memiliki pouvoir constituant, yaitu kekuasaan untuk membentuk undang-undang dasar dan undang-undang.

Dalam rangka desentralisasi dibentuk daerah otonom. Pada masa kini daerah otonomi tersebut adalah provinsi, kabupaten dan kota. Di bawah UU Nomor 22 Tahun 1999 Tentang Pemerintahan Daerah, Provinsi mempunyai status ganda: sebagai daerah otonom dalam rangka desentralisasi dan sebagai daerah (wilayah) administrasi dalam rangka dekonsentrasi dengan pimpinan Gubernur selaku Wakil Pemerintah. Provinsi merupakan daerah otonom administratif yang wilayah dan masyarakatnya meliputi (beberapa) kabupaten dan kota. Kabupaten adalah daerah otonom belaka yang sebagian besar masyarakatnya bercirikan perdesaan, sedangkan kota adalah daerah otonom belaka yang sebagian besar masyarakatnya bercirikan perkotaan. Kedua daerah otonom tersebut tidak berstatus ganda. Undang-undang menempatkan otonomi daerah secara utuh pada kabupaten dan kota. Dibandingkan provinsi, kabupaten dan kota berotonomi lebih luas.

Otonomi luas memberikan keleluasaan daerah otonom untuk menyelenggarakan otonomi yang mencakup kewenangan dalam berbagai bidang pemerintahan, kecuali kewenangan di bidang politik luar negeri, pertahanan keamanan, peradilan, moneter dan fiskal, agama serta kewenangan bidang lainnya yang diatur dalam Peraturan Pemerintah Nomor 25 Tahun 2000 Tentang Pembagian Wewenang Antara Pemerintah dan Provinsi. Di samping itu, keleluasaan otonomi mencakup pula kewenangan yang utuh dan bulat dalam penyelenggaraannya mulai dari perencanaan, pelaksanaan, pengawasan, pengendalian dan evaluasi.

Di samping otonomi yang luas, dianut pula dalam UU Nomor 22 Tahun 1999 otonomi nyata dan bertanggung jawab. Otonomi nyata adalah keleluasaan daerah otonom untuk menyelenggarakan kewenangan pemerintahan di bidang tertentu secara nyata ada dan diperlukan serta tumbuh, hidup dan berkembang di daerah. Sementara itu, otonomi yang bertanggung jawab adalah berupa perwujudan pertanggungjawaban sebagai konsekuensi pemberian hak dan kewenangan kepada daerah otonom dalam wujud tugas dan kewajiban yang harus dipikul oleh daerah otonom dalam mencapai tujuan pemberian otonomi, berupa peningkatan pelayanan kesejahteraan masyarakat yang semakin baik, pengembangan kehidupan demokrasi, keadilan dan pemerataan serta pemeliharaan hubungan yang serasi antara pusat dan daerah serta antar-daerah dalam rangka menjaga keutuhan Negara Kesatuan Republik Indonesia. 
Dalam Pasal 11 UU Nomor 22 Tahun 1999 Tentang Pemerintahan Daerah kewenangan Otonomi Kabupaten/Kota meliputi sebelas bidang pemerintahan atau urusan pemerintahan, yaitu pekerjaan umum, kesehatan, pendidikan dan kebudayaan, pertanian, perhubungan, investasi dan perdagangan, penanaman modal, lingkungan hidup, pertanahan, koperasi dan tenaga kerja. Bidang pemerintahan tersebut lebih banyak daripada bidang-bidang pemerintahan dalam UU Nomor 5 Tahun 1974 Tentang Pokok-Pokok Pemerintahan di Daerah.

Untuk mendukung penyelenggaraan otonomi daerah diatur dan ditentukan sumber-sumber keuangan Daerah, di antaranya Pajak Daerah yang diatur oleh UU Nomor 25 Tahun 1999 Tentang Perimbangan Keuangan Antara Pemerintah Pusat dan Daerah dan UU Nomor 34 Tahun 2000 Tentang Pajak Daerah dan Retribusi Daerah. Sumber keuangan daerah pada umumnya meliputi sumber keuangan sendiri dan bantuan oleh Pemerintah kepada daerah otonom. Pada umumnya sumber keuangan sendiri tidak mencukupi, sehingga diperlukan bantuan dari pemerintah. Ada sejumlah alasan yang mendasari perlunya bantuan dari pemerintah. Pertama, untuk mengatasi ketimpangan fiskal antara daerah otonom dan pemerintah. Sumber-sumber penerimaan pajak utama sebagian besar dikuasai Pemerintah.

Kedua, untuk mengatasi masalah ketimpangan fiskal antar-daerah otonom. Potensi penerimaan atau kemampuan daerah untuk menarik pendapatan sangat berbeda, bergantung pada kondisi daerah otonom yang bersangkutan dalam pemilikan sumber daya alam. Perbedaan tersebut dapat pula terjadi karena perbedaan kondisi penduduknya, seperti banyak atau sedikit, proporsi umur, dan tingkat ekonomi.

Ketiga, untuk menjaga standar layanan minimum di setiap daerah otonom. Daerah yang miskin perlu lebih banyak bantuan dari pemerintah.

Keempat, untuk mengatasi masalah yang timbul dari eksternalitas layanan ke wilayah (daerah) lain. Eksternalitas dapat terjadi juga mencakup penduduk di perbatasan antar daerah otonom.

Salah satu kota di Indonesia adalah Depok. Sebagaimana di daerah otonom lain, pemungutan pajak daerah di Kota Depok dilakukan oleh Dinas Pendapatan Daerah sebagaimana diatur dalam Peraturan Daerah Kota Depok Nomor 16 Tahun 2003 Tentang Pembentukan dan Penyusunan Organisasi Perangkat Daerah. Pemungutan pajak oleh Dinas tersebut berlangsung di enam kecamatan. Hasil yang dicapai memperlihatkan variasi di antara 
berbagai jenis pajak di enam kecamatan, sehingga menarik untuk diteliti.

\section{B. Permasalahan}

Seperti di negara berkembang lainnya, program desentralisasi di Indonesia diikuti oleh kecenderungan untuk semaksimal mungkin penggalian sumber-sumber keuangan sendiri atau sering disebut pendapatan asli daerah (PAD). Kecenderungan tersebut cukup beralasan, karena secara teoretik kemampuan daerah otonom untuk membiayai anggarannya merupakan salah satu kriteria utama dalam menilai kualitas otonomi daerah.

Argumen yang sering dikemukakan dalam menjelaskan hubungan antara kemampuan keuangan daerah otonom dan kualitas otonomi daerah adalah makin besar sumbangan pendapatan asli daerah terhadap anggaran pendapatan dan belanja daerah (APBD) berarti makin tinggi kualitas otonomi daerah dan sebaliknya. Semakin kecil sumbangan PAD berarti makin besar bantuan Pemerintah dan hal ini berarti semakin besar kebergantungan daerah otonom pada Pemerintah.

Berdasarkan argumen tersebut, Rondinelli mengatakan kemampuan daerah otonom untuk membiayai anggarannya merupakan inti utama dari konsep desentralisasi. Secara lengkap pendapat Rondinelli (1990:34) adalah:

Financial responsibility is the core of the concept of decentralization. If decentralization is to enable local organizations to provide urban services and infrastructure more effectivelly, they must have stronger authority to raise revenue and their capacity to generate larger amounts of revenue must be strengthened

Pendapat Rondinelli mengisyaratkan pentingnya PAD dalam APBD. Namun, dalam kenyataannya hasil kajian Booth ${ }^{5}$ dan Hal Hill sebagaimana dikutip oleh Salamm ${ }^{6}$ menunjukkan subsidi Pemerintah

5 Anne Booth, "Upaya-upaya Untuk Mendesentralisasikan Kebijaksanaan Perpajakan: Masalah Kemampuan Perpajakan, Usaha Perpajakan dan Perimbangan Keuangan", dalam Mac Andrews, C dan Amal, J., "Hubungan Pusat dan Daerah Dalam Pembangunan", (Jakarta: Rajawali Press, 1993), hal. 111-112.

${ }^{6}$ Alfatira Salamm, dan Hidayat Syarif, "Masalah Ekonomi dan Hubungan Keuangan Pusat-Daerah", dalam Haris, Syamsuddin "Paradigma baru Otonomi Daerah", (Jakarta: Pusat Penelitian Politik LIPI, 2001), hal. 159. 
terhadap daerah otonom sangat dominan. Dari sisi lain memandang kebergantungan daerah otonom kepada Pemerintah dalam keuangan sangat tinggi. ${ }^{7}$ Devas mengemukakan: ${ }^{8}$

....one of the main recurring concerns has been the dependence of local government on central government grants. Despite various attempts over the years to assign taxing ower to local government have generally remained low....

Salah satu elemen PAD adalah pajak daerah. Pajak daerah dinilai oleh Devas tidak potensial. Dalam UU Nomor 34 Tahun 2000 Tentang Pajak Daerah dan Retribusi Daerah disebutkan jenis pajak daerah bagi Provinsi, dan Kabupaten/Kota. Jenis-jenis pajak daerah bagi kabupaten/kota meliputi (a) pajak hotel, (b) pajak restoran, (c) pajak hiburan, (d) pajak reklame, (e) pajak penerangan jalan, (f) pajak pengambilan bahan galian golongan $\mathrm{C}$ dan $(\mathrm{g})$ pajak parkir. Realisasi hasil pemungutan pajak-pajak tersebut tentu bervariasi antar-daerah otonom, antar kecamatan dalam kabupaten/kota, dan antar-waktu.

Berdasarkan latar belakang yang diuraikan sebelumnya, permasalahan penelitian ini meliputi empat pertanyaan sebagai berikut:

1. Bagaimana kontribusi PAD terhadap APBD?

2. Bagaimana kontribusi pajak daerah terhadap Pendapatan Asli Daerah?

3. Bagaimana realisasi pemungutan pajak daerah di kecamatankecamatan Kota Depok?

4. Mengapa terjadi perbedaan realisasi pemungutan berbagai jenis Pajak Daerah tersebut di antara kecamatan-kecamatan Kota Depok?

${ }^{7}$ Nick Devas, "Local Government Finance in Indonesia : An overview, dalam Devas, Nick, Financing Local government in Indonesia", (Ohio University, Monographs in International Studies, Souteast Asia Series, No.84, 1989), hal. 17.

${ }^{8}$ Ibid., hal. 13. 


\section{Metode Penelitian}

Penelitian dilakukan di Depok. Depok merupakan daerah otonomi yang sebagian besar masyarakatnya bercirikan perkotaan. Kota diperkirakan akan makin banyak, sedangkan kabupaten makin sedikti jumlahnya di Pulau Jawa. Disamping itu, Kota Depok lahir di awal berlakunya UU No. 22 Tahun 1999 tentang Pemerintahan Daerah sebagai hasil konversi dari Kota Administratip di Kabupaten Dati II Bogor semasa UU No.5 Tahun 1974 tentang Pokok-pokok Pemerintahan di Daerah.

Dalam penelitian ini data primer diperoleh melalui wawancara mendalam dengan beberapa informan. Para informan terdiri atas Kepala Bappeda, Kepala Dispenda dan para sekretaris camat, seksi pemerintahan, seksi PBB di enam kecamatan. Wawancara dimaksudkan untuk mengkonfirmasikan data sekunder. Wawancara dengan pedoman wawancara.

Data sekunder berupa Peraturan Daerah tentang Pajak Daerah, APBD selama lima (5) tahun dan distribusi perolehan berbagai jenis pajak di enam kecamatan dalam tahun 2004. Distribusi perolehan pajak seperti ini tidak tertera dalam tahun anggaran 2000 sampai dengan 2003.

Sekalipun terdapat data kuantitatif, tetapi analisa penelitian bersifat kualitatif. Keterbatasan penelitian ini dijaga untuk tidak terlalu mengganggu hasil penelitian.

\section{Pembahasan}

Secara teoretik dan empirik pajak daerah terkait dengan otonomi daerah yang tercipta dalam penyelenggaraan desentralisasi oleh Pemerintah di Negara Kesatuan atau Pemerintah negara Bagian dalam konstruksi negara Federal. Oleh karena itu, beberapa konsep dasar dalam penyelenggaraan pemerintahan daerah perlu dibahas terlebih dahulu.

\section{A. Desentralisasi dan Otonomi Daerah}

Pada hakikatnya negara merupakan organisasi. Seperti organisasi lainnya, sejak lahir organisasi negara menganut sentralisasi. Sentralisasi berfungsi untuk menciptakan keseragaman dalam penyelenggaraan pemerintahan. Dengan asas sentralisasi terjadi keseragaman, baik kebijakan dan hukum maupun pelaksanaannya di seluruh wilayah dan masyarakat negara yang bersangkutan. Dalam kaitan sentralisasi kerapkali dianut pula dekonsentrasi. Dalam asas ini pembentukan kebijakan dan hukum secara terpusat pada pemerintah, 
sedangkan pelaksanaannya dilimpahkan kepada aparatur pemerintah di berbagai wilayah. ${ }^{9}$

Bagi organisasi negara yang besar dilihat dari aspek penduduk dan wilayah serta permasalahannya, kerapkali dianut pula desentralisasi. Desentralisasi berfungsi menciptakan keanekaragaman dalam penyelenggaraan pemerintahan. Dengan asas ini terjadi keanekaragaman kebijakan, hukum, dan pelaksanaannya sesuai dengan keanekaragaman masyarakat.

Dalam penyelenggaraan desentralisasi, diperlukan peraturan perundang-undangan yang (1) memberikan status badan hukum bagi daerah otonom, (2) menentukan batas-batas yurisdiksi dan fungsinya secara jelas, (3) memberikan kekuasaan untuk merencanakan, mengambil keputusan dan mengelola tugas-tugas publik, menyerahkan wewenang untuk mempekerjakan staf, (5) membangun aturan bagi interaksi antar-pemerintah daerah, (6) menarik sumbersumber pendapatan dan (7) mengelola sistem anggaran, pembukuan dan evaluasi. ${ }^{10}$ Penyelengaraan desentralisasi dilakukan oleh Pemerintah, sedangkan manifestasinya otonomi daerah diselenggarakan oleh berbagai lembaga pemerintahan daerah.

Desentralisasi dapat pula dipandang sebagai proses otonomisasi suatu masyarakat yang berada di wilayah tertentu. Proses tersebut menghasilkan pembentukan daerah otonom. Pembentukan daerah otonom tersebut dengan undang-undang. Daerah otonom adalah kesatuan masyarakat hukum yang memiliki batas-batas wilayah dan berotonomi, yaitu wewenang untuk membentuk dan melaksanakan kebijakan sendiri berdasarkan prakarsa sendiri. Oleh karena itu, Rondinelli dan kawan-kawan berpendapat desentralisasi merupakan the creation or strengthening financially or legally of subnational units of government, the activities of which are substantially outside the direct control of central government. Sejalan dengan pendapat ini, ${ }^{11}$ Mawhood memaparkan desentralisasi adalah: ${ }^{12}$

9 Bhenyamin Hoessein, "Hubungan Kewenangan Pusat dan Daerah", dalam buku "Pasang Surut Otonomi Daerah: Sketsa Perjalanan 100 tahun", (Institute for Local development dan Yayasan Tifa, 2005), hal. 198.

${ }^{10}$ John M. Cohen, dan Peterson, Stephen, B., “Administrative Decentralization, Strategies for Developing Countries. Connecticue”, (USA : Kumarian Press, 1999), hal. 17.

${ }^{11}$ Dennis A. Rondinelli, John R. Nellis, \& G, Shabbir Cheem, "Decentralization in developing Countries: A Review of Recent Experience", (Washington, DC: The World Bank, 1983), hal. 24. 
.....the creation of bodies separated by law from the national centre, in which local representatives are given formal power to decide on a range of public matthers. Their political base is the locallity and not as it is with commissioners and civil servants - The nation. Their area of authority is limited, but within that area their right to make decisions is entrenched by the law and can only be altered by new legislation. They have resources which, subject to the stated limits, are spent and invested at their own decisions.

Badan yang terbentuk dengan undang-undang tersebut di Indonesia disebut daerah otonom atau dalam negara Anglo Saxon disebut local government. Daerah otonom tersebut memiliki karakteristik tertentu. Mawhood menyebut karakteristik tersebut adalah (1) its own budget, (2) a separate legal existence, (3) the authority to allocate substantial resources, (4) on a range of different functions. ${ }^{13}$

Desentralisasi dipandang memberikan banyak manfaat, Sidik mencatat enam manfaat. Pertama, penyebaran pusat pengambilan keputusan (decongestion). ${ }^{14}$ Apabila semua masalah diletakkan di tangan seseorang atau sekelompok pengambil keputusan saja, dapat dipahami akan terjadi penumpukan (congestion) wewenang pada satu pusat pengambil keputusan saja, yang menyebabkan keterlambatan dalam pengambilan keputusan.

Kedua, kecepatan dalam pengambilan keputusan. Oleh karena tidak semua masalah perlu diputuskan oleh satu pusat pengambil keputusan saja, tentu pengambilan keputusan ini dapat dilaksanakan dengan lebih cepat. Apalagi di negara sedang berkembang, di mana transportasi dan komunikasi tidak selalu lancar, penyebaran wewenang kepada lebih dari satu pusat pengambil keputusan akan mempercepat proses pengambilan keputusan ini.

12 Philip Mawhood, "Local Government in the third World: The Experience of Tropical Africa. Chichester New York, Brisbane, Toronto, Singapore”,: (John Wiley \& Sons, 1983), hal. 2.

${ }^{13}$ Ibid., hal. 9-10.

${ }^{14}$ Machfud Sidik, Studi Empiris Desentralisasi Fiskal: Kebijakan Perimbangan Keuangan Pusat dan Daerah Di Era Otonomi Daerah. Makalah disampaikan pada Kuliah Perdana, Program Pascasarjana FISIP-Universitas Indonesia tanggal 27 Agustus 2001, hal. 56. 
Ketiga, pengambilan keputusan yang realistis (economic and social realism). Sangat sukar bagi seseorang pengambil keputusan yang tidak mengenal kondisi tempat di mana masalah itu timbul untuk mengambil keputusan yang realistis. Pengambil keputusan di tingkat pusat akan sulit memahami kondisi lokal, ataupun kondisi sosial (kebiasaan dan tradisi), khususnya untuk negara yang masyarakatnya mempunyai kebudayaan yang beraneka ragam.

Keempat, penghematan (economic-efficiency). Sebagian besar argumentasi teori mengenai desentralisasi meyakini adanya peningkatan efisiensi alokasi sumber daya dan meningkatkan economic welfare masyarakat lokal. Efisiensi ekonomi ini dapat dicapai melalui peningkatan adanya akuntabilitas, dan membuat pelayanan publik lebih responsif terhadap permintaan masyarakat lokal. Hal ini berarti juga dapat meningkatkan willingness to pay for services, tentu pemerintah lokal akan lebih mampu untuk mempertahankan kualitas pelayanan publik sesuai dengan permintaan masyarakatnya. Penghematan ekonomi dapat dicapai, antara lain, melalui upaya yang lebih ekonomis memperkerjakan tenaga setempat daripada mengirimkan pejabat dari pusat ke daerah, yang memerlukan biaya perjalanan dan sebagainya.

Kelima, keikutsertaan masyarakat lokal (local participation). Sentralisasi akan mudah menimbulkan perasaan masa bodoh pada masyarakat lokal karena menganggap semua kebutuhan mereka akan dipenuhi oleh pemerintah pusat, tanpa mereka harus berusaha sendiri. Kadang-kadang masyarakat lokal merasa tidak ada kaitan antara pajak yang dibayar dengan pelayanan yang diterima. Atau sebaliknya, masyarakat lokal merasa kebutuhannya tidak diperhatikan oleh pemerintah pusat, walaupun dalam kenyataannya pengeluaran pemerintah pusat untuk daerah yang bersangkutan relatif besar. Desentralisasi akan memberikan peluang dan mempromosikan kepedulian masyarakat pada program pemerintah daerah melalui partisipasi masyarakat lokal dalam pengambilan keputusan publik.

Keenam, solidaritas nasional (national solidarity). Pendapat umum mengatakan kesatuan nasional dapat dibina melalui perencanaan terpusat dan bukan dengan memberikan kesempatan kepada masing-masing daerah menurut cara mereka sendiri. Namun, sebenarnya pemberian kesempatan seperti itu dapat menyalurkan aspirasi masyarakat lokal sedemikian rupa, sehingga perasaan suatu daerah tidak diperhatikan. Sementara itu, daerah lainnya mendapat perhatian terlalu besar dapat dihilangkan. Solidaritas nasional justru dapat dibina dengan memberikan kesempatan pendelegasian 
wewenang dalam sistem desentralisasi, dan sekaligus menghilangkan kediktatoran dan pengambilan keputusan.

Penyelenggaraan otonomi daerah bertalian erat dengan keuangan otonomi daerah otonom. Pertama, daerah otonom merupakan badan hukum. Oleh karena itu, daerah otonom mempunyai keuangan yang terpisah dari keuangan Pemerintah. Kedua, kewenangan yang diserahkan kepada daerah otonom oleh Pemerintah, termasuk kewenangan dalam urusan keuangan. Ketiga, penyelenggaraan otonomi daerah menuntut dukungan sumber keuangan. Tanpa dukungan keuangan, otonomi daerah tidak akan terealisasikan. Rondinelli dan kawan-kawan memandang otonomi keuangan merupakan jantung otonomi daerah. ${ }^{15}$

Pada dasarnya sumber keuangan daerah otonom meliputi sumber keuangan sendiri (pendapatan asli daerah) dan perimbangan keuangan antara Pemerintah dan Daerah dengan formula finance should follow functions. Semakin besar sumber kuangan sendiri dibandingkan bantuan dari pemerintah semakin kuat otonomi daerah.

\section{B. Pajak Daerah}

Salah satu sumber keuangan sendiri dari daerah otonom adalah pajak daerah. Soelarno mendefinisikan pajak daerah sebagai: ${ }^{16}$

Pajak asli daerah atau pajak negara yang diserahkan kepada daerah, yang pemungutannya diselenggarakan oleh daerah di dalam wilayah kekuasannya, yang gunanya untuk membiayai pengeluaran daerah di dalam wilayah kekuasaannya berhubung tugas dan kewajiban mengatur dan mengurus rumah tangganya sendiri.

Menurut Davey pajak daerah meliputi: ${ }^{17}$

1) pajak yang dipungut oleh Pemerintah Daerah dengan dasar pengaturan dari Daerah itu sendiri;

${ }^{15}$ Rondinelli, Op. Cit., hal. 48.

${ }^{16}$ Slamet Soelarno, "Pajak Daerah dan Retribusi Daerah", (Jakarta: Penerbit STIALAN), hal. 87.

${ }^{17}$ Kenneth J. Davey, "Pembiayaan Pemerintah Daerah", (Jakarta: UI Press, 1988), hal. $39-40$. 
2) pajak yang dipungut berdasarkan peraturan nasional tetapi penetapan tarifnya dilakukan oleh Pemerintah Daerah.

3) Pajak yang ditetapkan dan dipungut oleh Pemerintah Daerah itu sendiri

4) Pajak yang dipungut dan di administrasikan oleh Pemerintah Pusat tetapi hasil pemungutannya diberikan sebahagian atau dengan kata lain bahwa pajak tersebut dibagihasilkan Pemerintah Pusat dengan Pemerintah Daerah (opsenten)

Berdasarkan hukum nasional, pajak daerah merupakan iuran wajib yang diberikan oleh orang pribadi atau badan kepada daerah otonom tanpa imbalan langsung yang seimbang. Iuran tersebut dapat dipaksakan berdasarkan perundang-undangan yang berlaku. Menurut James dan Nobes, "A tox is a compulsory levy made by public authorities for which nothing is received in return. Iuran tersebut digunakan untuk membiayai penyelenggaraan pemerintahan daerah dan pembangunan daerah. ${ }^{18}$

Pada masa kini berdasarkan UU Nomor 34 Tahun 2000 Tentang Pajak Daerah dan Retribusi Daerah, pajak daerah meliputi jenis-jenis pajak bagi provinsi dan jenis-jenis pajak bagi kabupaten/kota. Pajak Provinsi terdiri dari: (a) Pajak kendaraan Bermotor (PKB) dan Kendaraan Di Atas Air, (b) Bea Balik Nama KB (BBN-KB) dan Kendaraan Di Atas Air, (c) Pajak Bahan Bakar Kendaraan Bermotor (PBB-KB), (d) Pajak Pengambilan dan Pemanfaatan Air Bawah Tanah dan Air Permukaan, sedangkan pajak Kabupaten/Kota terdiri dari: (a) Pajak Hotel dan Restoran (PHR), (b) Pajak Hiburan (PHi), (c) Pajak hotel dan restoran, (d) Pajak Penerangan Jalan (PPJ), (e) Pajak Pengambilan bahan galian Golongan C, (f) Pajak Parkir.

Berbeda dengan UU Nomor 18 Tahun 1997, bagi kabupaten dan kota yang semula pajak hotel dan pajak restoran disatukan, kini pajak tersebut dibedakan. Pajak pengambilan dan pengolahan bahan galian golongan $\mathrm{C}$ diubah menjadi pajak pengambilan bahan galian golongan C. Di samping itu, muncul pula pajak parkir yang semula tidak diatur sebagai pajak daerah. Pajak parkir ini dikenakan atas penyelengaraan tempat parkir di luar badan jalan oleh orang pribadi atau badan, baik yang disediakan sebagai suatu usaha, termasuk penyediaan tempat penitipan kendaraan bermotor dan garasi kendaraan bermotor yang memungut bayaran.

18 James Simon \& Christopher Nobes, "The Economic of Taxation Principles", (Policy and Practice Europe: Prentice Hall, 1996), hal. 237. 
Jenis pajak provinsi bersifat limitatif. Provinsi tidak berwenang memungut pajak di luar ke empat jenis pajak yang telah di tentukan oleh undang-undang. Sementara itu, jenis pajak kabupaten/kota tidak bersifat limitatif. Kabupaten/kota berwenang memungut pajak di luar dari ketujuh jenis pajak yang telah ditentukan oleh undang-undang dengan kriteria tertentu. ${ }^{19}$ Kriteria tersebut adalah:

a. bersifat pajak dan bukan retribusi;

b. objek pajak terletak atau terdapat diwilayah kabupaten/kota yang bersangkutan dan mempunyai mobilitas yang cukup rendah, serta hanya melayani masyarakat diwilayah kabupaten/ kota yang bersangkutan;

c. objek dan dasar pengenaan pajak tidak bertentangan dengan kepentingan umum;

d. objek pajak bukan merupakan objek pajak provinsi dan/atau objek pajak pusat;

e. potensinya memadai.

f. tidak memberikan dampak ekonomi yang negatif;

g. memperhatikan aspek keadilan dan kemampuan masyarakat;

h. menjaga kelestarian lingkungan.

Pajak daerah merupakan salah satu sumber utama bagi Pendapatan Asli Daerah (PAD) di samping sumber-sumber yang lainnya. Sebagai perwujudan otonomi daerah, daerah harus mampu mengelola rumah tangganya sendiri. Untuk itu dibutuhkan dana yang cukup, yang berasal dari sumber-sumber yang mampu menghasilkan pendapatan secara berkesinambungan. Pendapatan asli daerah sangat dibutuhkan untuk membiayai penyelenggaraan pemerintahan, pembangunan dan pelayanan masyarakat. Oleh karena itu, ketersediaan sumber dana yang berasal dari pendapatan asli daerah secara berkelanjutan akan menjadi faktor yang menentukan bagi terwujudnya otonomi daerah.

Pemungutan pajak daerah selain didasarkan dan dilaksanakan berdasarkan asas-asas dan sistem perpajakan, juga harus memperhatikan hal-hal seperti (1) keadilan, dalam arti pungutan itu harus bersifat umum, merata dan menurut kekuatan; (2) secara ekonomis dapat diterima, yakni pungutan tersebut tidak dapat merusak sumber-sumber kemakmuran rakyat; (3) dapat dicapai tujuannya,

${ }^{19}$ Ning Rahayu, Penerimaan Pajak Sebagai Salah Satu Sumber Pembiayaan Dalam Rangka Otonomi Daerah Dan Permasalahan-Permasalahan, dalam Jurnal Bisnis \& Birokrasi, No. 02/Vol.XIII/Mei/2005, hal. 178-179. 
dalam arti pungutan itu jangan sampai mengakibatkan adanya kemungkinan penyelundupan atau pengurangan hasil karena tarifnya terlalu tinggi.

Pemungutan pajak daerah merupakan suatu rangkaian kegiatan, mulai dari penghimpunan data objek dan subjek sampai kegiatan penagihan pajak kepada wajib pajak serta pengawasan penyetorannya. Sementara itu, tata cara pemungutan merupakan rangkaian tata kerja yang saling berkaitan, yang kemudian membentuk pola kerja dalam rangka pelaksanaan bidang kerja pemungutan atau pengenaannya. Dengan demikian, pengertian tata cara pemungutan pajak adalah kegiatan untuk mengenakan pajak (penata usahaan, pendataan, penetapan, penagihan, pengawasan, termasuk penyelesaian sengketa) sesuai dengan pola kerja yang ditetapkan. ${ }^{20}$

Pajak Daerah mencakup semua pajak yang dipungut oleh daerah berdasarkan peraturan yang berlaku. Dalam kebijakan pemungutannya, menurut Davey perlu mempertimbangkan beberapa kriteria kecukupan dan elastisitas, keadilan, kemampuan administratif dan kesepakatan politis. $^{21}$

Menurut Nurmantu (1994: 26) terdapat dua fungsi pajak, yaitu fungsi budgetair dan fungsi regulerend. Fungsi pertama disebut pula sebagai fungsi utama pajak, yang kerap disebut pula sebagai fiskal. Fungsi budgetair memandang pajak sebagai alat untuk memasukkan dana secara optimal ke kas negara berdasarkan undang-undang perpajakan. Dalam hal pajak daerah tentu bukan kas negara melainkan kas daerah. Fungsi budgetair disebut fungsi utama pajak karena fungsi inilah yang secara historis pertama kali muncul dengan pengenaan pajak. Fungsi kedua adalah fungsi regulerend (mengatur). Dengan fungsi ini pajak sebagai alat untuk mengatur atau melaksanakan kebijakan pemerintah (daerah) dalam bidang sosial dan ekonomi. Fungsi ini dipandang sebagai fungsi tambahan dari pajak, karena fungsi ini merupakan pelengkap dari fungsi pertama dan digunakan untuk mencapai tujuan tertentu.

Pendapatan dari pajak harus menghasilkan pendapatan yang cukup besar dalam kaitannya dengan seluruh atau sebagian biaya pelaksanaan yang akan dikeluarkan. Untuk itu penerimaan pajak harus elastis atau mampu menyesuaikan diri dengan perkembangan yang terjadi. Elastisitas dalam hal ini menyangkut 2 (dua) hal, yaitu:

\footnotetext{
${ }^{20}$ Soelarno, Op. Cit., 112.

${ }^{21}$ Davey, Op. Cit., hal. 40-49.
} 
1) pertumbuhan potensial dari dasar pengenaan pajak yang bersangkutan;

2) kemudahan untuk memungut pertumbuhan pajak tersebut.

Pada prinsipnya beban pengeluaran pemerintah harus dipikul oleh semua golongan dalam masyarakat secara adil. Demikian pula dengan beban pajak. Beban pajak juga harus didistribusikan secara adil pula kepada masyarakat. Keadilan ini mencakup dua hal, yakni keadilan secara vertikal dan keadilan secara horizontal.

Pengelolaan pajak menuntut adanya kemampuan administrasi, sebab berbagai pungutan pajak berbeda-beda baik jumlah, integritas dan keputusannya. Semuanya menuntut adanya administrasi yang baik yang mampu mendukung berbagai kegiatan tersebut.

Kesepakatan politis dalam hal ini meliputi kemauan politis yang diperlukan dalam mengenakan pajak, struktur tarif, memutuskan siapa yang harus membayar dan bagaimana pajak yang ditetapkan, memungut pajaknya dan penerapan sanksi. Dalam pajak daerah, kemauan politik berasal dari Kepala Daerah $(\mathrm{KDH})$ dan DPRD.

\section{Realisasi Pemungutan Pajak Daerah}

Keberhasilan dari realisasi pemungutan pajak daerah bergantung pada beberapa faktor, khususnya sistem perpajakan daerah. Sebagaimana sistem perpajakan pusat, sistem perpajakan daerah meliputi kebijakan perpajakan daerah, hukum perpajakan daerah dan administrasi perpajakan daerah.

Menurut Mansury, kebijakan perpajakan merupakan proses awal dalam sistem perpajakan, karena pada proses tersebut dilakukan penentuan jenis dan besaran tarif pungutan pajak. ${ }^{22}$ Cakupan kebijakan perpajakan meliputi pemilihan objek, subyek dan tarif serta persyaratannya yang secara prinsip disepakati untuk dimuat dalam hukum perpajakan.

Hukum perpajakan mengakomodasi kebijakan perpajakan, sehingga menjadi pilar legitimasi pemungutan pajak. Dalam konteks ini Mansury mengatakan hukum pajak adalah seperangkat peraturan perpajakan yang terdiri dari undang-undang beserta peraturan pelaksanaannya. $^{23}$

hal. 18.

${ }^{22}$ R. Mansury, "Pajak Penghasilan Lanjutan”, (Jakarta: Indonesia - Hill Co, 1996),

${ }^{23}$ Ibid., hal. 20. 
Instrumen operasional dari kebijakan dan hukum pajak adalah administrrasi perpajakan yang meliputi aspek organisasi, fungsi, SDM, peralatan dan sistem serta prosesdur, biaya pemungutan dan proses administrasi. Menurut Mansury administrasi perpajakan mengandung tiga pengertian. ${ }^{24}$ Pertama, instansi atau badan yang diberikan wewenang dan tanggung jawab untuk menyelenggarakan pemungutan pajak. Kedua, orang-orang yang terdiri dari pejabat dan pegawai yang bekerja pada instansi perpajakan yang secara nyata melaksanakan kegiatan pemungutan pajak. Ketiga, kegiatan penyelenggaraan pemungutan pajak oleh suatu instansi atau badan yang dilaksanakan untuk mencapai sasaran dalam kebijakan perpajakan berdasarkan sarana hukum yang ditentukan oleh undang-undang perpajakan.

Pada tataran otonomi daerah, administrasi perpajakan dalam ketiga pengertian di atas mengacu pada Dinas Pendapatan Daerah. Namun, perlu dipahami pula, peranan Dinas tersebut juga besar dalam penyusunan kebijakan dan Peraturan Daerah tentang pajak. Oleh karena itu, administrasi perpajakan menurut Mansury merupakan faktor yang sangat penting dalam penerimaan pajak daerah. ${ }^{25} \mathrm{Hal}$ ini sesuai dengan pendapat Norman D. Novack menyatakan: ${ }^{26}$

\begin{abstract}
Administrasi perpajakan merupakan kunci keberhasilan pelaksanaan kebijakan perpajakan. Tugas administrasi perpajakan tidak membuat kebijakan atau memutuskan siapa-siapa yang dikenakan dan dikecualikan dari pemungutan pajak, juga tidak menentukan obyek pajak baru. Sebagai sarana pelaksanaan undang-undang perpajakan, administrasi perpajakan perlu disusun dengan sebaik-baiknya, sehingga mampu menjadi instrumen yang bekerja secara efektif dan efisien, sebab jika tidak efektif dan efisien maka sasaran sistem perpajakan tidak dapat dicapai.
\end{abstract}

Berdasarkan pendapat tersebut, dapat disarikan administrasi perpajakan yang baik apabila mampu menghasilkan penerimaan yang memadai dari berbagai jenis pajak. Dasar-dasar terselenggaranya administrasi perpajakan yang baik adalah:

\footnotetext{
${ }^{24}$ Ibid., hal. 23.

${ }^{25}$ Ibid., hal. 24.

${ }^{26}$ Ibid., hal. 24 .
} 
a. kejelasan dan kesederhanaan dari ketentuan undang-undang yang memudahkan bagi administrator dan wajib pajak;

b. kesederhanaan akan mengurangi penyelundupan pajak, karena dapat memberikan kemudahan untuk dipahami dan dilaksanakan oleh aparat ataupun pemenuhan pajak oleh wajib pajak;

c. reformasi perpajakan yang realistis harus mempertimbangkan kemudahan tercapainya efisiensi dan efektif perlu disusun dengan pengumpulan dani pemanfaatan informasi tentang subyek dan obyek pajak.

Dari sisi lain, Jantscher dan Bird menyatakan:

Administrasi pajak yang terbaik bukanlah semata-mata sebagai usaha pengumpulan seluruh pendapatan, namun bagaimana pendapatan itu sendiri dapat ditingkatkan. Administrasi pajak yang berkualitas buruk dapat mengumpulkan sejumlah besar dari sektor-serktor yang mudah dikenai pajak, seperti pendapatan upah, sementara tidak mampu menyerahkan pajak atas perusahaanperusahaan dan pekerjaan-pekerjaan bisnis.

Oleh karena itu, tingkat pengumpulan merupakan ukuran efektivitas administrasi pajak yang agak kurang canggih. Ukuran yang lebih akurat adalah 'celah pemungutan', yaitu celah di antara pendapatan pajak aktual dan potensial, berbeda di antara sektor-sektor wajib pajak yang berbeda.

Para administrator pajak sering mengalami kesulitan untuk memperbaiki peningkatan penerimaan pajak, karena sejumlah persoalan yang menyangkut tarif pajak, pembebasan dan masa pembayaran yang sebagian tidak dapat dilaksanakan secara tepat dan tegas dengan alasan-alasan psikologi tertentu. Di berbagai negara berkembang perbaikan administrasi perpajakan sering dilakukan dengan penyederhanaan sistem perpajakan yang ada, sehingga sistem tersebut dapat diterapkan dengan efektif.

Jantscher dan Bird juga memberikan syarat lain bagi keberhasilan perbaikan administrasi pajak, yaitu:

Adanya komitmen yang kuat untuk memperbaiki manajemen dan pengambilan kebijakan, selain itu juga tingkat kecakapan teknik tertentu termasuk didalamnya, penentuan langkah-langkah yang perlu guna memperbaiki kualitas administrasi pajak dengan tunjangan politik penuh 
dari pihak berwenang tertinggi. Tanpa komitmen dan bantuan tersebut, usaha-usaha perbaikan yang didesain dengan sangat baikpun pada akhirnya tidak akan berhasil.

Dengan demikian, perbaikan administrasi pajak yang berhasil pada umumnya mempunyai tiga syarat, yaitu penyederhanaan, strategi dan komitmen. Walaupun diakui bagaimanapun tidak ada rangkaian program yang sekali diterapkan akan dapat menjamin perbaikan administrasi perpajakan di suatu negara.

Kegiatan administrasi perpajakan merupakan proses yang mencakup semua kegiatan untuk melaksanakan berbagai fungsi administrasi perpajakan. Secara garis besar mencakup kegiatan: (a) melakukan pendataan/identifikasi subyek dan/atau obyek pajak, (b) melakukan penilaian (assessment) dan penetapan nilai pajak terhutang, (c) melakukan penagihan atau penerimaan setoran pajak, (d) melakukan pembukuan penerimaan pajak dan (e) menegakkan hukum atau aturan perpajakan .

Di samping, terdapatnya variasi potensi antar daerah otonom dan antar-kecamatan dalam daerah otonom, Ning mengemukakan sejumlah permasalahan yang dihadapi dalam perpajakan daerah. Pertama, masih rendahnya basis pajak daerah. ${ }^{27}$ Kedua, sangat ketatnya kriteria pengadaan pajak baru. Ketiga, kemampuan perencanaan dan administrasi pemungutan pajak daerah masih rendah. Keempat, pengawasan keuangan yang lemah mengakibatkan kebocorankebocoran dalam penerimaan daerah. Keempat permasalahan tersebut terpulang pada kondisi SDM daerah otonom, khususnya SDM di Dinas Pendapatan Daerah Kota Depok.

\section{Gambaran Umum Kota Depok}

Depok bermula dari sebuah Kecamatan yang berada dalam lingkungan Kewedanaan Wilayah Parung Kabupaten Daerah Tingkat II Bogor. Berdasarkan Peraturan Pemerintah Nomor 43 Tahun 1981 Depok ditetapkan sebagai Kota Administratip, karena secara geografis dinilai merupakan kawasan strategis dan berbatasan langsung dengan wilayah pengembangan Jabotabek. Dalam perkembangannya, Kota Administratip Depok tumbuh dengan sangat cepat. Jumlah penduduk Kotip Depok yang semula sekitar 200 ribu jiwa pada 1981, berkembang hampir 2,5 kali lipat pada 1998. Melihat

${ }^{27}$ Ning, Op. Cit., hal. 180-183. 
kepesatan tersebut dan sesuai dengan Undang-undang Nomor 22 Tahun 1999 Kotip Depok dikonversi menjadi Kota Depok pada 20 April 1999 berdasarkan Undang-Undang Republik Indonesia Nomor 15 Tahun 1999.

\section{Pemerintah Kota}

Kota Depok memiliki 13 Dinas dan tujuh Lembaga Teknis Daerah. Sesuai dengan UU Nomor 22 Tahun 1999 dan UU Nomor 34 Tahun 2000, pajak dan retribusi daerah ditetapkan dengan Peraturan Daerah oleh Kepala Daerah (Walikota) bersama DPRD. Menurut UU Nomor 34 Tahun 2000, Rancangan Peraturan Daerah tersebut perlu disosialisasikan terlebih dahulu.

Sebagai kota baru, Kota Depok mempunyai beberapa permasalahan yang terkait dengan kapasitas Pemerintah Daerah, yaitu (1) masih kurangnya kualitas dan kuantitas sumber daya manusia aparatur; (2) masih terbatasnya ketersediaan sumber-sumber pembiayaan; (3) serta masih kurang sarana dan prasarana yang dapat mendukung fungsi pelayanan umum; (4) terbatasnya Akses dan Rendahnya Mutu Layanan Kesehatan: mengakibatkan rendahnya derajat kesehatan masyarakat, keterbatasan layanan kesehatan, kurangnya pemahaman reproduksi.

Dalam menjalankan roda Pemerintahan, Kota Depok dibagi dalam enam kecamatan dan 63 kelurahan, yaitu kecamatan Cimanggis mempunyai tiga belas kelurahan, kecamatan sawangan mempuyai empat belas kelurahan, kecamatan Limo mempunyai delapan kelurahan, kecamatan Pancoran Mas mempunyai sebelas kelurahan, kecamatan Beji mempunyai enam kelurahan dan kecamatan Sukmajaya mempunyai sebelas kelurahan

\section{Kontribusi PAD terhadap APBD}

Dalam UU No. 22 Tahun 1999 Pendapatan Asli Daerah (PAD) bersumber pada pajak daerah, retribusi daerah, hasil (laba) usaha daerah dan lain-lain pendapatan asli daerah yang sah. 
Tabel 1

Perbandingan PAD dan Non PAD di Depok

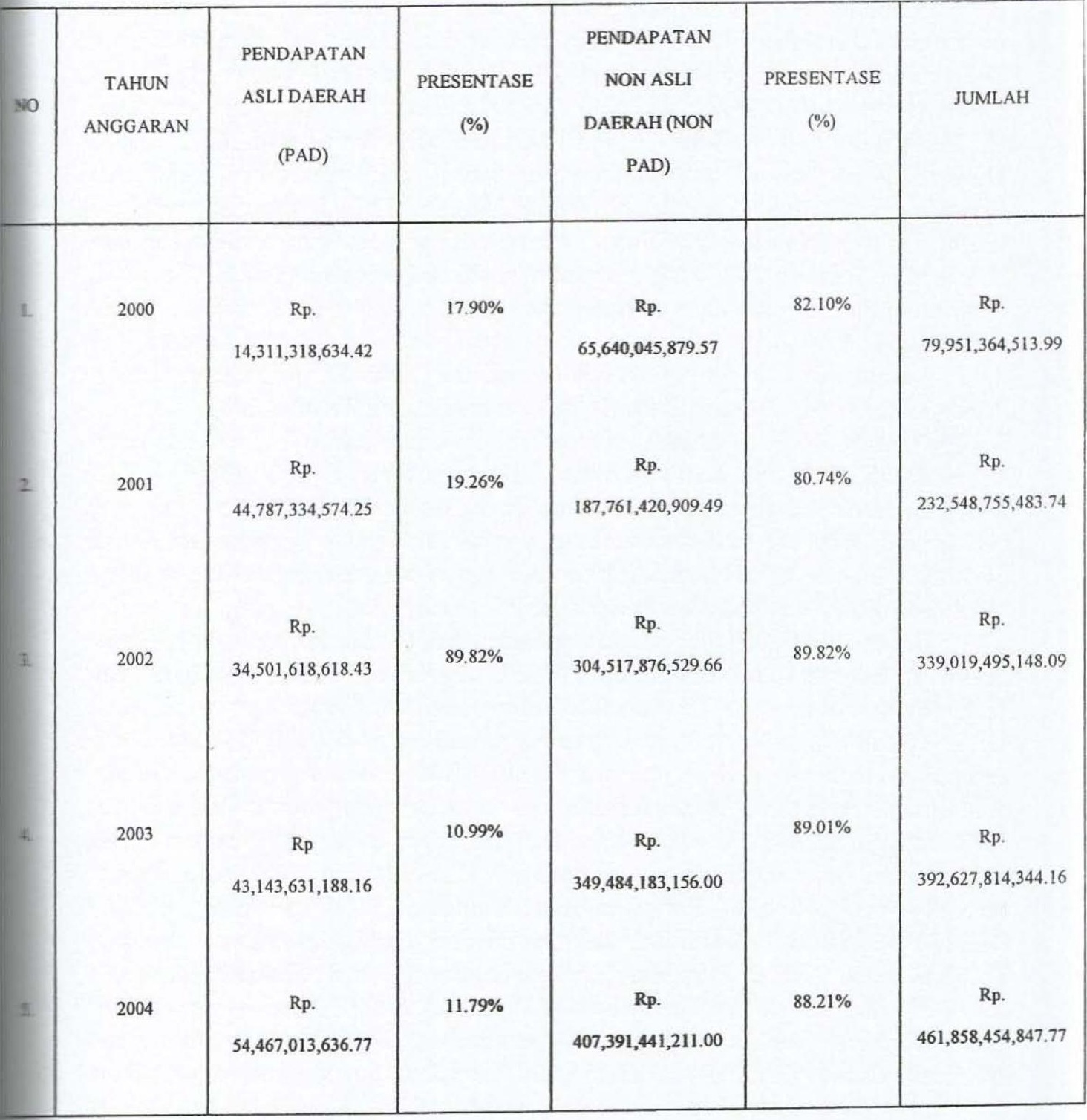

(Sumber Data: Kantor Dinas Pendapatan Daerah Kota Depok 2005)

Tabel 1 menunjukkan bahwa rata-rata PAD tiap tahun sebesar $14 \%$, sedangkan rata-rata pendapatan non asli daerah sebesar $86 \%$. Hal ini menunjukkan ketergantungan Kota Depok kepada Pemerintah sangat besar. 
Menurut Cochrane dan Devas, apabila besarnya PAD kurang dari $20 \%$ dari keseluruhan APBD menimbulkan ketidak mandirian daerah otonom. ${ }^{28}$.

Sementara itu, Dana Perimbangan yang diterima Depok selalu meningkat. Jumlah pendapatan yang berasal dari Dana Perimbangan Tahun 2000 adalah sebesar Rp.65.506.698.375. Jumlah ini terdiri dari Bagi Hasil Pajak sebesar Rp.13.620.449.130,- Bagi Hasil Bukan Pajak sebesar Rp.195.851.309 dan Dana Alokasi Umum sebesar Rp.44.662.241.643. Disamping itu, masih terdapat transfer tunai yang bersumber dari Dana Perimbangan Propinsi sebesar Rp.7.028.156.293. Dari komposisi tersebut, terlihat bahwa Dana Alokasi Umum merupakan pos penerimaan terbesar atas keseluruhan penerimaan yang berasal dari Dana Perimbangan atau 68,18\%. Kemudian disusul oleh dana perimbangan yang berasal dari Bagi Hasil Pajak sebesar $20,79 \%$.

Dalam tahun berikutnya terjadi kenaikan Dana Perimbangan. Jumlah Pendapatan yang berasal dari Dana Perimbangan Tahun 2001 menjadi Rp.171.082.589.413. Jumlah ini terdiri dari Bagi Hasil Pajak sebesar Rp.6.291.352.224 dan Dana Alokasi Umum sebesar Rp.102.776.611.000. Dari komposisi tersebut, terlihat bahwa Dana Alokasi Umum merupakan pos penerimaan terbesar atas keseluruhan penerimaan yang berasal dari Dana Perimbangan atau $60,07 \%$ disusul kemudian dengan dana perimbangan yang berasal dari bagi hasil pajak sebesar $20,63 \%$

Dalam tahun 2002, jumlah pendapatan yang berasal dari Dana Perimbangan adalah sebesar Rp.239.026.321.297. Jumlah ini terdiri dari bagi hasil pajak sebesar Rp.41.610.998.442 dan Bagi hasil Bukan Pajak sebesar Rp.8.936.529.982; Dana Alokasi Umum sebesar Rp.160.110.000.000. Dari komposisi tersebut, terlihat bahwa Dana Alokasi umum merupakan pos penerimaan terbesar atas keseluruhan penerimaan yang berasal dari Dana Perimbangan atau $66.98 \%$, disusul kemudian dari dana perimbangan yang berasal dari bagi Hasil Pajak sebesar 17,41\%. Jumlah Pendapatan yang berasal dari Dana Perimbangan Tahun 2003 adalah sebesar Rp.333.596.588.337,00. Jumlah ini terdiri dari Bagi Hasil Pajak sebesar Rp.61.679.060.978,00; Bagi Hasil Bukan Pajak sebesar Rp.9.465.858.203,00 dan Dana Alokasi Umum sebesar Rp.209.550.000.000,00. Disamping itu, masih terdapat cash transfer yang bersumber dari Dana Perimbangan Propinsi sebesar Rp.52.901.669.156,00. Dari komposisi tersebut, terlihat

28 Glyn Cochrane, "Policies For Strengthening Local Government in Developing Countries, World Bank Working Paper No. 582. Management and Development Series No. 9", (Washington DC: The World Bank, 1983), hal. 10. Lihat juga Nick Devas, "Local Government Finance in Indonesia: An overview, dalam Devas, Nick, Financing Local government in Indonesia", (Ohio University: Monographs in International Studies, Souteast Asia Series, No.84, 1989), hal. 46. 
bahwa Dana Alokasi Umum merupakan pos penerimaan terbesar atas keseluruhan penerimaan yang berasal dari Dana Perimbangan atau $62,82 \%$ dan disusul kemudian dengan dana perimbangan yang berasal dari Propinsi sebesar $15,86 \%$.

Pada tahun 2004, jumlah pendapatan yang berasal dari Dana Perimbangan adalah sebesar Rp.396.658.892.211,00. Jumlah ini terdiri dari Bagi Hasil Pajak sebesar Rp.11.623.890.373,00; Bagi Hasil Bukan Pajak sebesar Rp.11.623.890.373,00; Dana Alokasi Umum Rp.227.627.000.000,00 dan Dana Alokasi Khusus Rp.4.778.680.000,00. Disamping itu, masih terdapat cash transfer yang bersumber dari Dana Perimbangan Propinsi sebesar Rp.75.535.589.351,00. Dari komposisi tersebut, terlihat bahwa Dana Alokasi Umum merupakan pos penerimaan terbesar atas keseluruhan penerimaan yang berasal dari Dana Perimbangan atau 57,36\% dan disusul kemudian oleh Bagi Hasil Pajak sebesar 19,48\%.

Simanjuntak mencatat kecenderungan makin besarnya transfer dari Pemerintah ke daerah otonomi di berbagai negara. ${ }^{29}$ Perlunya transfer tersebut karena beberapa hal: Pertama, untuk mengatasi persoalan ketimpangan fiscal vertical. Penguasaan pajak pusat sangat besar dibandingkan pajak daerah. Kedua, untuk mengatasi ketimpangan fiscal horizontal. Hal ini bertalian dengan variasinya kemampuan daerah otonom dalam menghimpun pendapatan. Hal ini juga bertalian dengan kondisi setempat. Ketiga, adanya kewajiban untuk menjaga tercapainya standard pelayanan minimum di setiap daerah otonom. Keempat, untuk mengatasi persoalan yang timbul dari menyebar atau melimpahnya efek pelayanan pabrik. Kelima, untuk rehabilitasi yaitu untuk mencapai tujuan stabilator pemerintah pusat.

Sementara itu, Pendapatan Asli Daerah Kota Depok Tahun 2000 adalah sebesar Rp.14.311.318.634,42. Jumlah ini terdiri dari Pajak Daerah sebesar Rp. 7.150.537.088; Retribusi Daerah sebesar Rp.6.926.199.143 dan lain-lain Pendapatan Asli Daerah sebesar Rp.234.582.403,50. Dari komposisi PAD tersebut, terlihat bahwa ratio antara Pajak Daerah dengan Retribusi Daerah terhadap total PAD hampir berimbang.

Pendapatan Asli Daerah Kota Depok Tahun 2001 meningkat menjadi Rp.44.787.334.575. Jumlah ini terdiri dari Pajak Daerah sebesar Rp.32.034.260.466,279; Retribusi Daerah sebesar Rp.11.409.274.130 dan Bagian Laba Usaha Daerah sebesar Rp.9.894.385. Dari komposisi PAD tersebut, terlihat bahwa Pajak Daerah dan Retribusi Daerah relatif

${ }^{29}$ Robert A. Simanjuntak, "Hubungan Keuangan Pusat dan Daerah dalam Pasang Surut Otonomi Daerah: Sketsa Perjalanan 100 Tahun", (Diterbitkan oleh Institute For Local Development, Yayasan Tifa, 2005), hal. 274-276. 
berimbang. Selain itu juga terlihat bahwa jumlah Pajak Daerah Tahun 2001 mengalami peningkatan sebesar 126,69\% dibandingkan dengan jumlah Pajak Daerah tahun 2000. Ini merupakan dampak logis dari adanya kebijakan dan program peningkatan PAD Kota Depok.

Dalam tahun 2002, Pendapatan Asli Daerah Kota Depok adalah sebesar Rp.34.501.618.619. Jumlah ini terdiri dari pajak Daerah sebesar Rp.18.989.797.301; Retribusi Daerah sebesar Rp.13.211.537.915; Bagian Laba Usaha Daerah sebesar Rp.252.610.363 dan lain-lain Pendapatan Asli Daerah sebesar Rp.2.047.673.039. Dari komposisi PAD tersebut, terlihat bahwa Pajak Daerah memberikan kontribusi terbesar, yakni sebesar 55,04\%. Dibandingkan tahun sebelumnya, Pajak daerah Tahun 2002 mengalami kenaikan sebesar $36,51 \%$.

Pendapatan Asli Kota Depok Tahun 2003 adalah sebesar Rp.43.143.631.189,14. Jumlah ini terdiri dari Pajak Daerah sebesar Rp.23.588.459.511,39, Retribusi Daerah sebesar Rp.16.544.809.595,65 dan lain-lain Pendapatan Asli Daerah adalah sebesar Rp.2.193.810.475,08. Dari komposisi PAD tersebut, terlihat bahwa Retribusi Pajak Daerah dan Retribusi Daerah terhadap total PAD masing-masing sebesar $54,1 \%$ dan $38,85 \%$.

Dalam tahun 2004, realisasi Pendapatan Asli Kota Depok adalah sebesar Rp.54.467.013.636,73. Jumlah ini terdiri dari Pajak Daerah sebesar Rp.27.541.667.232,29, Retribusi Daerah sebesar Rp.23.472.219.704,22, dan lain-lain pendapatan Daerah sebesar Rp.2.412.407.633,26. Dari komposisi PAD tersebut terlihat bahwa ratio antara Pajak Daerah dengan Retribusi Daerah terhadap total PAD hampir berimbang yakni $50,57 \%$ dan $43,09 \%$.

Tabel 1 secara umum menunjukkan terdapatnya peningkatan jumlah pemasukan ke kas daerah, yaitu pada táhun 2001 terdapat kenaikan sebesar Rp.30.476.015.939,83 tetapi pada tahun 2002 terdapat penurunan penerimaan Pendapatan Asli Daerah sebesar Rp.10.286.715.955,82. Hal ini terjadi karena adanya perubahan perundang-undangan keuangan daerah kota Depok dan penyesuaian administrasi di Dinas Pendapatan Daerah Kota Depok.

Pada tahun 2003 terdapat kenaikan penerimaan Pendapatan Asli Daerah sebesar Rp.8.642.012.569,73 dan pada tahun 2004 terjadi lagi kenaikan penerimaan Pendapatan Asli Daerah sebesar Rp.11.323.382.448,61. Kenaikan dalam penerimaan Pendapatan Asli Daerah di Kota Depok disebabkan oleh beberapa factor, antara lain bertambah luasnya wilayah Kota Depok, pertambahan penduduk, makin berkembangnya tingkat perekonomian masyarakat, makin banyak perkantoran dan pertokoan di wilayah Depok, makin tinggi pendidikan masyarakat sehingga kesadaran akan kewajiban membayar pajak juga meningkat. Semakin berkembangnya 
suatu kota maka akan berpengaruh terhadap perkembangan perekonomian wilayah tersebut. Semakin berkembangnya perekonomian suatu wilayah akan meningkatkan jumlah wajib pajak. Semakin banyak wajib pajak daerah yang patuh untuk membayar pajak maka akan meningkat pula penerimaan Pendapatan Asli Daerah.

PAD mencerminkan local taxing power yang cukup sebagai kondisi yang diperlukan bagi terwujudnya otonomi daerah yang luas. Dengan demikian, keinginan daerah otonom untuk meningkatkan penerimaan pajak dan retribusi adalah sah dengan tetap mematuhi prinsip keuangan negara agar pajak dan retribusi daerah tidak destorsif dan menyebabkan inefisiensi ekonomi. ${ }^{30}$

Tabel 2 tentang Rincian Pendapatan Asli Daerah menunjukkan bahwa Pendapatan Asli Daerah Kota Depok merupakan penerimaan dari beberapa pos penerimaan daerah yaitu (1) Pos Pajak Daerah, (2) Pos Retribusi Daerah, (3) Pos Laba Usaha Daerah dan, (4) Pos lain-lain Pendapatan Asli Daerah yang sah. Masing-masing kontribusinya terhadap PAD berlainan.

Pajak Daerah di Kota Depok sejak tahun 2000 sampai tahun 2004 secara umum menunjukkan kenaikan, tetapi pada tahun 2002 terjadi penurunan penerimaan pajak sebesar Rp.13.044.463.165,27. Hal ini terjadi karena adanya perubahan perundang-undangan dan penyesuaian administrasi di Dinas Pendapatan Daerah Kota Depok. Sejak tahun 2003 sampai sekarang penerimaan pajak daerah di kota Depok setiap tahunnya mengalami peningkatan.

Setelah pajak daerah, retribusi daerah menduduki peringkat kedua. Retribusi Daerah di Kota Depok meliputi (1). Retribusi Pelayanan Kesehatan, (2). Retribusi Pelayanan Persampahan/Kebersihan, (3). Retribusi Penggantian biaya Cetak KTP dan Akta Catatan Sipil, (4). Retribusi Pelayanan Pemakaman dan pengabuan mayat, (5). Retribusi Parkir ditepi jalan umum, (6). Retribusi Pasar, (7). Retribusi Terminal, (8). Retribusi Parkir Khusus, (9). Retribusi Penyedotan kakus, (10). Retribusi Rumah Potong Hewan, (11). Retribusi Tempat Rekreasi dan Olah Raga, (12). Retribusi Ijin Mendirikan Bangunan, (13). Retribusi Ijin Gangguan, (14). Retribusi Ijin Trayek, (15) Retribusi Ijin Peruntukan Penggunaan tanah. Retribusi tersebut terbagi dalam tiga kelompok. Pertama retribusi jasa umum dengan ciri-ciri : (a) bersifat bukan pajak dan bersifat bukan retribusi jasa usaha atau retribusi perizinan tertentu; (b) jasa yang bersangkutan merupakan kewenangan daerah otonomi dalam rangka pelaksanaan desentralisasi. (c) Jasa tersebut memberi manfaat khusus bagi orang pribadi atau badan yang diharuskan membayar retribusi di samping untuk melayani kepentingan dan

${ }^{30}$ Simanjutak, Ibid., hal. 280. 
kemanfaatan umum. (d) Jasa tersebut layak dikenakan retribusi. (e) Retribusi tidak bertentangan dengan kebijakan nasional mengenai penyelenggaraannya. (f) retribusi dapat dipungut secara efektif dan efisien serta merupakan salah satu sumber pendapatan daerah yang potensial, dan (g) pemungutan tersebut memungkinkan penyediaan jasa tersebut dengan tingkat dan/atau kualitas pelayanan yang lebih baik. Kedua, retribusi jasa usaha dengan ciri-ciri (a) bersifat bukan pajak dan bukan retribusi jasa umum atau retribusi perizinan tertentu, dan (b) jasa yang dimaksud adalah jasa yang bersifat komersial yang seyogyanya disediakan oleh sektor swasta tetapi belum memadai atau terdapatnya harta yang dimilki/dikuasai daerah yang belum dimanfaatkan secara penuh oleh Pemda. Ketiga, retribusi perizinan dengan ciri-ciri (a) perizinan tersebut termasuk kewenangan pemerintah yang diserahkan kepada Pemda, (b) perizinan tersebut benar-benar diperlukan guna melindungi kepentingan umum dan (c) biaya yang menjadi beban daerah dalam penyelenggaraan izin tersebut dan biaya untuk menanggulangi dampak negatif dari pemberian izin tersebut cukup besar sehingga layak dibiayai dari retribusi perizinan.

Laba Usaha Daerah Kota Depok hanya berasal dari (1). Perusahaan air minum daerah dan (2). Bank Pembangunan Daerah. Pada tahun 2000 Laba Usaha Daerah di Kota Depok belum memberikan pemasukan kepada Pendapatan Asli Daerah, karena masa transisi dari Kota Administrasi menjadi Kota, sehingga administrasi pemerintahan masih dalam penyesuaian. Tahun 2001 Laba Usaha Daerah mulai memberikan pemasukan kepada Pendapatan Asli Daerah. Demikian juga pada tahun-tahun berikutnya Laba Usaha Daerah selalu menunjukkan peningkatan dalam penerimaan kas daerah.

Pos lain-lain Pendapatan Asli Daerah yang sah sejak tahun 2000 selalu menunjukkan peningkatan penerimaan setiap tahunnya. Pos ini terdiri dari: (1). Hasil penjualan asset daerah yang tidak terpakai, contohnya: mobil, motor, (2). Penerimaan Jasa Giro Kas Daerah, (3). Konstribusi Pasar Depok Jaya, dan (4). Penerimaan lain-lain.

\section{Faktor-Faktor yang Berdampak Terhadap Disparitas Perolehan Jenis Pajak antar Kecamatan.}

Uraian di atas menunjukkan besarnya perolehan tiap jenis pajak daerah berbeda di antara kecamatan. Pertama, hal tersebut sebagai dampak perbedaan fungsi rencana wilayah kecamatan. Kedua, hal tersebut sebagai akibat perbedaan potensi kecamatan. Ketiga, bertahan dengan administrasi 
perpajakan. Ketiga faktor tersebut di atas berakar pada kinerja organisasi Dinas Pendapatan Daerah.

Dari hasil wawancara diperoleh kesan kinerja Dinas Pendapatan Daerah belum maximum. Hal ini karena SDM-nya secara kuantitas kurang mencukupi dan secara kualitas masih rendah.

\section{Penutup}

\section{A. Kesimpulan}

Secara keseluruhan kontribusi PAD terhadap APBD tergolong kecil. Sebaliknya kontribusi bantuan keuangan dari pemerintah tergolong besar. Hal ini berarti terdapat kebergantungan kota Depok pada Pemerintah tergolong besar dalam hal keuangan daerah. Hal ini berarti pula kondisi otonomi daerah Kota Depok tergolong kecil.

Bantuan Pemerintah tersebut dalam bentuk Dana Alokasi Umum. Hingga kini Kota Depok belum pernah menggunakan Dana Alokasi Khusus. Kota Depok juga tidak menerima bagi hasil dalam bidang sumber daya alam, karena Depok tidak memiliki banyak sumber daya alam.

Kontribusi Pajak Daerah terhadap PAD lebih besar dibandingkan kontribusi jenis-jenis PAD lainnya seperti retribusi daerah dan hasil perusahaan daerah. Hal ini mengisyaratkan belum maksimalnya pelayanan umum yang menghasilkan retribusi. Cita-cita UU Nomor 22 Tahun 1999 menitikberatkan layanan pada Kabupaten/Kota belum terwujud.

Dari berbagai jenis pajak daerah, pajak penerangan jalan menduduki teratas, disusul oleh pajak restoran. Sementara itu, pajak parkir menduduki perangkat terakhir. Kedua jenis pajak penerangan jalan dan restoran tersebut mengenai kebutuhan hampir semua orang, karena itu perangkatnya tinggi. Sementara pajak parkir bertalian dengan kendaraan bermotor yang tidak di miliki oleh semua orang.

Pajak Restoran dominan di tiap kecamatan, hal terjadi karena kebutuhan akan makan, terutama makanan siap saji hampir ada di setiap kecamatan terutama untuk wilayah perindustrian, perkantoran /bisnis dan hiburan.

Pajak Hotel dan Rumah Kost yang tertinggi diberikan oleh kecamatan Beji. Wilayah kecamatan Beji merupakan wilayah yang paling banyak terdapat lembaga pendidikan dan perkantoran sehingga kebutuhan akan rumah kos sangat tinggi. Wilayah kecamatan Beji merupakan wilayah pusat pendidikan di kota Depok. 
Pajak Hiburan yang paling besar diberikan oleh kecamatan Cimanggis, kemudian disusul oleh kecamatan Pancoran Mas, kecamatan Limo, kecamatan Beji, kecamatan Sawangan dan terakhir kecamatan Sukmajaya. Pajak Hiburan diatur dalam Peraturan Daerah Nomor 02 Tahun 2002.

Pajak Parkir yang paling besar diberikan oleh kecamatan Beji.

Pajak penerangan jalan merupakan pajak daerah terbesar di Kota Depok. Sejak 2000 sampai dengan 2004 pajak penerangan jalan selalu meningkat. Dalam mengelola pajak ini pemerintah kota Depok bekerja sama dengan Perusahaan Listrik Negara. Pembayaran pajak ini dilakukan oleh masyarakat langsung bersama dengan pembayaran listriknya.

Pajak Reklame dikelola oleh Dinas Pendapatan Daerah bekerja sama dengan Dinas Kebersihan dan Lingkungan Hidup reklame. Pajak Reklame diatur dalam Peraturan daerah Nomor 02 Tahun 2002.

Tiap kecamatan di kota Depok mempunyai kemampuan yang berbeda-beda dalam memberikan pajak daerah. Hal yang menyebabkan variasi tersebut adalah perbedaan potensi pajak di tiap kecamatan dan kualitas SDM yang dimiliki oleh Dinas Pendapatan Daerah.

\section{B. Saran}

Perlu dilakukan intensifikasi dan ekstensifikasi pajak-pajak daerah dan perlu dilakukan penelitian kinerja SDM Dinas Pendapatan Daerah untuk meningkatkan Pendapatan Asli Daerah. 


\section{Daftar Pustaka}

\section{Buku}

Booth, Anne. Upaya-upaya Untuk Mendesentralisasikan Kebijaksanaan Perpajakan: Masalah Kemampuan Perpajakan, Usaha Perpajakan dan Perimbangan Keuangan, dalam Mac Andrews, C dan Amal, J., Hubungan Pusat dan Daerah Dalam Pembangunan, Jakarta: Rajawali Press, 1993.

Cochrane, Glyn. Policies For Strengthening Local Government in Developing Countries, World Bank Working Paper No. 582. Management and Development Series No. 9, Washington D.C.: The World Bank, 1983.

Cohen, John, M \& Peterson, Stephen, B. Administrative Decentralization, Strategies for Developing Countries, Connecticut, USA: Kumarian Press, 1999.

Hoessein, Bhenyamin. Hubungan Kewenangan Pusat dan Daerah, dalam buku Pasang Surut Otonomi Daerah: Sketsa Perjalanan 100 tahun, Institute for Local development dan Yayasan Tifa, 2005.

Davey, Kenneth J. Pembiayaan Pemerintah daerah, Jakarta: UI Press, 1988.

Devas, Nick. Keuangan Pemerintah Daerah di Indonesia: Sebuah Tinjauan Umum dalam Devas Nick, Keuangan Pemerintah di Indonesia, Jakarta: UI Press, 1989.

Devas, Nick. Local Government Finance in Indonesia: An overview, dalam Devas, Nick, Financing Local Government in Indonesia, Ohio University, Monographs in International Studies, Souteast Asia Series, No.84, 1989.

James Simon \& Christopher Nobes. The Economic of Taxation Principles, Policy and Practice Europe: Prentice Hall, 1996.

Kranenburg, R. Algemene Staatsleer, Haarlem: H.D. Tjeenk Willink \& Zoon N.V. 1955

Mansury, R. Pajak Penghasilan Lanjutan, Jakarta: Indonesia - Hill Co, 1996

Mawhood, Philip. Local Government in the third World: The Experience of Tropical Africa, Chichester New York, Brisbane, Toronto, Singapure: John Wiley \& Sons, 1983. 
Rahayu, Ning. "Penerimaan Pajak Sebagai Salah Satu Sumber Pembiayaan Dalam Rangka Otonomi Daerah Dan Permasalahan-Permasalahan", Jurnal Bisnis \& Birokrasi, No. 02/Vol.XIII/Mei/2005.

Richard M. Bird and Milka Cassanegra Jantsecher, (ed). Improving Tax Administration in Developing Countries, Washington, DC. IMF, 1992

Rondinelli, Dennis, A, John R. Nellis, \& G, Shabbir Cheem. Decentralization in developing Countries: A Review of Recent Experience, Washington, D.C.: The World Bank, 1983.

Rondinelli, Dennis, A. Decentralizing Urban Development Program, Washington, D.C. Office of Housing and Urban Programs. U.S. Agency for International Development, 1990.

Salamm, Alfitra dan Hidayat Syarif. Masalah Ekonomi dan Hubungan Keuangan Pusat-Daerah dalam Syamsudin Haris, Paradigma Baru Otonomi Daerah, Pusat Penelitian Politik LIPI, 2001.

Sidik, Machfud. Studi Empiris Desentralisasi Fiskal: Kebijakan Perimbangan Keuangan Pusat dan Daerah Di Era Otonomi Daerah. Makalah disampaikan pada Kuliah Perdana, Program Pascasarjana FISIP-Universitas Indonesia tanggal 27 Agustus 2001.

Simanjuntak, Robert A. Hubungan Keuangan Pusat dan Daerah dalam Pasang Surut Otonomi Daerah: Sketsa Perjalanan 100 Tahun, Diterbitkan oleh Institute For Local Development, Yayasan Tifa, 2005.

Shah, Anwar \& Theresa Thompson. Implementing Decentralized Local Government: A Treacherous Road With Potholes, Detours and Road Closure: prepared for "Can Decentralization Help Rebuild Indonesia"?, A Conference Sponsored by the International Studies Program, Andrew Young School of Policy Studies, Georgia State University, Atlanta, May 1-3, 2002.

Soelarno, Slamet. Pajak Daerah dan Retribusi Daerah, Jakarta: Penerbit STIA-LAN.

Strong, CF. Modern Political Constitution: An Introduction to the Comparative Study of Their History and Exciting Fa, London: Sidgwick \& Jackson Limited, 1960.

\section{Peraturan Perundang-undangan}

Republik Indonesia. Undang-Undang Dasar 1945. 
Republik Indonesia. Undang-Undang No: 22 Tahun 1999 tentang Pemerintahan Daerah

Republik Indonesia. Undang-Undang No: 25 Tahun 1999 tentang Perimbangan Keuangan antara Pemerintah Pusat dan Daerah.

Republik Indonesia. Undang-Undang No. 34 Tahun 2000 tentang Pajak Daerah dan Retribusi Daerah.

Kota Depok. Peraturan Daerah No.02 Tahun 2002 tentang Pajak Hotel, Pajak Hiburan, Pajak Reklame, Pajak Restoran dan Pajak Parkir.

Kota Depok. Peraturan Daerah No. 12 Tahun 2002 tentang Pajak Penerangan Jalan.

Kota Depok. Peraturan Daerah No. 16 Tahun 2003 tentang Struktur Organisasi Dinas Pendapatan Daerah Kota Depok.

\section{Lain-lain}

Badan Perencana Daerah Kota Depok. "Kinerja Kota Depok Capaian Pelaksanaan Pembangunan Tahun 2000-Tahun 2004".

Badan Perencana Daerah dan Badan Pusat Statistik Kota Depok. "Indikator Kesejahteraan Rakyat Kota Depok Tahun 2003“.

Dinas Pendapatan Daerah Kota Depok. "Sosialisasi Pajak Daerah".

Pemerintah Daerah Kota Depok. "Laporan Keterangan Pertanggungjawaban Walikota Depok 2000-2004“.

Pemerintah Daerah Kota Depok. "Profil Usaha Kecil dan Menengah Kota Depok“.

Kecamatan Beji Kota Depok. "Laporan Tahunan Camat Beji Tahun 2004".

Kecamatan Beji Kota Depok. "Data Monografi Kecamatan“, 2004.

Kecamatan Cimanggis Kota Depok. "Laporan Tahunan Camat Cimanggis 2004".

Kecamatan Cimanggis Kota Depok. "Data Monografi Kecamatan Tahun 2004".

Kecamatan Limo Kota Depok. "Selayang Pandang Kecamatan Limo“.

Kecamatan Limo Kota Depok. "Data Monografi Kecamatan Limo Tahun 2004". 
Kecamatan Pancoran Mas Kota Depok. "Data Monografi Kecamatan Pancoran Mas Tahun 2004".

Kecamatan Pancoran Mas Kota Depok. "Selayang Pandang Kecamatan Pancoran Mas", 2004.

Kecamatan Sawangan Kota Depok. "Data Monografi Kecamatan Sawangan Tahun 2004".

Kecamatan Sawangan Kota Depok. "Laporan Tahunan Camat Sawangan Kota Depok“, 2004.

Kecamatan Sukmajaya Kota Depok. "Data Monografi Kecamatan", 2004.

Kecamatan Sukmajaya Kota Depok. "Laporan Tahunan Camat Sukmajaya Kota Depok Tahun 2004". 